\title{
Functional antigenics
}

\section{Determining which antigens are functional in a range of diseases is likely to produce the second wave of immunotherapies.}

\author{
Aris Persidis
}

At present, drug leads based on the immune system account for more new medicines in development than any other categoryapproximately $30 \%$ of the total'. Despite this dominant role in drug development, certain therapeutic approaches, such as stimulating the immune system to fight cancer, or, conversely, neutralizing it in autoimmune disease, have proven to be elusive. It has been difficult to find disease-specific antigens that trigger clinically effective immune system responses. Most drug developers who have taken this therapeutic route blame the inability to precisely define the antigens that drive the immune reactions as the central problem. New technologies are emerging that address antigen identification in much more sophisticated ways than were previously possible. Because these new systems begin by collecting and amino-acid sequencing cell-surface peptides, and then attempting to find which of these peptides are the functional antigens, the field has been dubbed "functional antigenics," based on an analogy with functional genomics ${ }^{2}$. If functional antigenic approaches are successful in identifying new antigenic targets, these technologies should pave the way for a second generation of important new drug leads.

\section{Historical perspective}

Therapies based on stimulating the immune system have generally followed one of two paths. Nonspecific approaches deliver molecules that are meant to stimulate the entire immune system into action. In the majority of cases these are cytokines that elevate basal levels of immune system activity and thereby offer the body a competitive edge in fighting disease. Alternatively, specific immunotherapies employ pieces of an invading pathogen, such as a bacterium, virus, or of a cancer cell itself, to stimulate the production of antibodies and cytotoxic $\mathrm{T}$ lymphocytes (CTLs). Perhaps the best example of a specific immunotherapy is the smallpox vaccine. In a relatively short time it has practically eradicated the disease from the world's population.

While using antigens to produce antibody

Aris Persidis is vice president for business development at Argonex Inc., 2044 India Road, Suite 202, Charlottesville, VA 22901 (apersidis@argonex.com) responses is relatively straightforward, antibodies, by themselves, are capable only of neutralizing some invading organisms. The key to killing diseased cells, as in cancer, where antibodies play a limited role, is to elicit a CTL response, where an antigen is recognized, and the antigen-bearing diseased cells are then killed by the CTLs.

Because CTLs are the actual killing mechanism directed against diseased cells, there has been a tremendous effort to understand what signals are necessary to stimulate CTLs into action in, say cancer, or to stop them from attacking transplants or self-tissue in autoimmune disease. The concept is that if drug developers understood what cues CTLs use to attack a specific cell, therapeutics could be created that would turn this CTL killing power on or off as needed. That antigens recognized by CTLs have therapeutic potential is supported by direct and indirect evidence in cancer, infectious disease, autoimmune disease, and host versus graft disease (Table 1) ${ }^{3}$. Cancer attracts perhaps the greatest efforts, because of the inherent advantages of immunotherapies over chemotherapy and radiation-based treatments. This effort dates back to 1982, when it was demonstrated that CTLs recognizing tumor cells could be isolated from patients. This showed that there was an anticancer immune response and suggested that its encouragement might have therapeutic benefits $^{4}$. Since then, highly specific CTLs have been shown to recognize antigens in prostate, colorectal, ovarian, breast, pancreatic, and renal tumors, as well as adenocarcinomas, sarcomas, and squamous tumors of the lung and of the head and neck.

What seems to be the key driver in this recognition process is a peptide fragment in the major histocompatibility complex class I (MHC-I) cleft presented to the CTLs. Peptide antigens arrive on the cell surface of target cells for CTL recognition through the so-called

\begin{tabular}{|c|c|c|c|}
\hline Disease & Source molecule & Antigen & Discovery method \\
\hline \multicolumn{4}{|l|}{ Cancer } \\
\hline Breast cancer & HER2/neu & Three distinct peptides & Motif analysis \\
\hline $\begin{array}{l}\text { Head and } \\
\text { neck cancer }\end{array}$ & CASP-8 & One peptide & Genetic method \\
\hline Lung cancer & HER $2 /$ neu & One peptide & Motif analysis \\
\hline Melanoma & $\begin{array}{l}\text { BAGE; CDK-4; GAGE-1,2; } \\
\text { gp100; gp43; MAGE-1; } \\
\text { MAGE-3; MART-1; MCIR; } \\
\text { MUM-1; TRP-1; TRP-2; } \\
\text { tyrosinase; } \beta \text {-catenin }\end{array}$ & 35 distinct peptides & $\begin{array}{l}\text { Mass spectrometry; } \\
\text { motif analysis; genetic } \\
\text { method }\end{array}$ \\
\hline Ovarian cancer & HER2/neu & Seven distinct peptides & Motif analysis \\
\hline Pancreatic cancer & HER2/neu & One peptide & Motif analysis \\
\hline Prostate cancer & Prostate specific antigen & Three distinct peptides & Motif analysis \\
\hline Renal cancer & RAGE1 & One peptide & Genetic method \\
\hline \multicolumn{4}{|c|}{ Infectious diseases } \\
\hline Bacterial infections & Lipids and lipoglycans & $\begin{array}{l}\text { Mycolic acid, } \\
\text { lipoarabinomannan }\end{array}$ & Mass spectrometry \\
\hline Bacterial infections & Isopentenyl pyrophosphate & $\begin{array}{l}\text { Isopentenyl } \\
\text { pyrophosphate }\end{array}$ & Fractionation analysis \\
\hline Tuberculosis & AhpC & One peptide & Motif analysis \\
\hline Flu virus & Nucleoprotein & One peptide & Genetic method \\
\hline HIV & Surface glycoprotein & Two peptides & Genetic method \\
\hline \multicolumn{4}{|c|}{ Autoimmune disease } \\
\hline $\begin{array}{l}\text { Demyelinating } \\
\text { polyneuritis }\end{array}$ & Peripheral myelin & PO $180-199$ peptide & $\begin{array}{l}\text { Prior antibody } \\
\text { recognition }\end{array}$ \\
\hline
\end{tabular}


Table 2. Companies developing functional antigenics.

\begin{tabular}{|c|c|c|}
\hline Company & Approach & Area \\
\hline $\begin{array}{l}\text { Argonex Inc. } \\
\text { (Charlottesville, VA) }\end{array}$ & $\begin{array}{l}\text { DIRECT platform: attomole-level mass } \\
\text { spectrometry coupled with CTL assays for } \\
\text { antigen identification }\end{array}$ & $\begin{array}{l}\text { Melanoma, ovarian, breast, } \\
\text { colorectal, prostate, head and } \\
\text { neck cancers; autoimmune } \\
\text { disease; infectious disease }\end{array}$ \\
\hline $\begin{array}{l}\text { Cantab } \\
\text { (Cambridge, UK) }\end{array}$ & $\begin{array}{l}\text { Viral DISC technology for delivery of DNA } \\
\text { encoding for peptide antigens }\end{array}$ & $\begin{array}{l}\text { Cancer; autoimmune disease; } \\
\text { infectious disease }\end{array}$ \\
\hline $\begin{array}{l}\text { Corixa Inc. } \\
\text { (Seattle, WA) }\end{array}$ & $\begin{array}{l}\text { Motif analysis for MHC-I peptide antigen } \\
\text { identification, and antigen microsphere } \\
\text { delivery system }\end{array}$ & $\begin{array}{l}\text { Breast and prostate cancer; } \\
\text { tuberculosis }\end{array}$ \\
\hline $\begin{array}{l}\text { CTL Therapeutics } \\
\text { (Seattle, WA) }\end{array}$ & $\begin{array}{l}\text { Polymer-based delivery of DNA encoding } \\
\text { for peptide antigens }\end{array}$ & Cancer; infectious disease \\
\hline $\begin{array}{l}\text { CYTImmune Corp. } \\
\text { (College Park, MD) }\end{array}$ & $\begin{array}{l}\text { Polymer-based delivery of DNA encoding } \\
\text { for peptide antigens }\end{array}$ & Cancer; infectious disease \\
\hline $\begin{array}{l}\text { Dendreon Corp. } \\
\text { (Mountain View, CA) }\end{array}$ & Dendritic cell-based antigen delivery & Cancer; viral infections \\
\hline $\begin{array}{l}\text { Epimmune Inc. } \\
\text { (San Diego, CA) }\end{array}$ & $\begin{array}{l}\text { PADRE immunostimulant technology; } \\
\text { ex vivo cell therapy }\end{array}$ & Cancer; infectious disease \\
\hline $\begin{array}{l}\text { ImmunoDesigned } \\
\text { Molecules (Paris) }\end{array}$ & $\begin{array}{l}\text { Macrophage stimulation and dendritic } \\
\text { cell antigen delivery }\end{array}$ & Cancer; infectious disease \\
\hline $\begin{array}{l}\text { Pangea Inc. } \\
\text { (Cambridge, MA) }\end{array}$ & $\begin{array}{l}\text { Motif analysis for MHC-I peptide antigen id- } \\
\text { entification, and ENSPHERE delivery system }\end{array}$ & Cancer; infectious disease \\
\hline $\begin{array}{l}\text { Virus Research Inst. } \\
\text { (Cambridge, MA) }\end{array}$ & $\begin{array}{l}\text { Viral delivery of DNA encoding for peptide } \\
\text { antigens }\end{array}$ & Cancer; infectious disease \\
\hline $\begin{array}{l}\text { Therion Biologics } \\
\text { (Cambridge, MA) }\end{array}$ & $\begin{array}{l}\text { Viral delivery of DNA encoding for peptide } \\
\text { antigens }\end{array}$ & $\begin{array}{l}\text { Melanoma; colorectal, } \\
\text { breast, lung cancer; AIDS }\end{array}$ \\
\hline
\end{tabular}

antigen presentation pathway: Viral, bacterial, or tumor-specific proteins are degraded inside the cell, and the resulting peptides are then shuttled to the cell surface for presentation. At that point the peptides are sitting in the binding pockets of the $\mathrm{MHC}$ molecules, and circulating CTLs that recognize these peptides attack and destroy those cells.

There are a number of lines of evidence that harnessing this recognition process could lead to effective therapeutics. In prostrate cancer, for example, a peptide derived from the prostate specific membrane antigen (PSMA) stimulates CTLs in vitro. Some patients who were given PSMA peptide as part of their therapy showed a reduction in their PSMA levels. In vitro stimulation of CTLs has also been demonstrated with melanoma peptides ${ }^{6}$, which has been correlated positively with tumor regression in some patients who were treated with these peptides. Finally, mouse models of various tumors have demonstrated that tumor-specific antigens that stimulate CTLs can block tumor progression, can cause tumor regression, and can confer long-term protection from future tumor challenge?.

\section{State of the art}

There are three methods that enable the identification of $\mathrm{MHC}$-displayed antigens: the motif, the genetic, and the mass spectrometry analytical method (Table 1). The motif get cells that express the appropriate MHC molecules. As the transfected DNA is expressed, it is recognized as foreign and degraded by the antigen presentation pathway outlined above. Once these cells are recognized by CTLs in in vitro screening assays, the sequence of the peptide recognized is determined by further subcloning and screening, followed by confirmation that duplicates the exact sequence synthetically".

The advantage of the genetic method is its efficiency and requirement of relatively small amounts of experimental material. However, like the motif approach, it is limited in that it cannot identify modified peptides or nonpeptide CTL-inducing antigens.

The mass spectrometry approach overcomes the limitations of the other two methods--but at a cost. In this approach, all peptides that reside in all the MHC molecules on the surface of target cells are extracted and fractionated by multiple rounds of chromatography. Fractions that elicit a CTL response are then analyzed by mass spectrometry by timing the passage of each fraction through the mass spectrometer with the simultaneous deposition of the fraction into a CTL assay. Positive CTL assays correspond directly with specific peptides that are being sequenced at that very same moment by the mass spectrometer ${ }^{12}$.

The disadvantages of this method are that it requires more cells than the other methods, and it depends on the availability of MHCmatched tumor and CTL cell lines. The latter applies to the other methods as well. The advantages are that it detects the native antigen that elicits a CTL response, without guesswork, and it can identify peptides that have been modified posttranslationally as well as nonpeptide antigens, which no other approach can deliver.

\section{Industry challenges}

Companies involved in functional antigenics (Table 2) have two essential challenges. First, they need to demonstrate the ability to find and synthesize antigens that will elicit a strong, sustained, and specific CTL response against specific disease targets. While each of the three antigen identification methods has certain advantages, the key to finding disease-specific antigens the most efficiently will depend on the nature of the target itself. If an unmodified peptide antigen from a bacterium or a virus with a small genome is sufficient to provoke the CTL response, then either motif generation or genetic approaches will deliver important information relatively quickly, depending on how much is known about the disease target. However, in cases where nothing is known about the antigen, or it is posttranslationally modified or a nonpeptide, then only the mass spectrometry method can deliver the actual antigens displayed on the cell surface. 
Second, how can companies deliver the therapeutic antigen so that it will provoke the desired CTL response? Simple peptide injections have not worked because the free peptide is rapidly degraded in the bloodstream. Direct injection of DNA formulations coding for the peptide antigen have had little success because they are also degraded rapidly. Because the current consensus is that dendritic cells can induce CTL responses to viral, bacterial, and tumor antigens more efficiently than other professional antigen-presenting cells, several companies have focused their antigen delivery methods on them (Table 2$)^{13}$. Antigen is delivered either in a targeted, controlled-release, encapsulated form, or as a DNA sequence that is targeted to, for example, the dendritic cells.

\section{The future}

Several developments bode well for functional antigenics efforts. Advances in the sensitivity of mass spectrometry to the attomole level will reduce the amount of cells used in antigen identification by a factor of ten, accelerating this process. Also, with the realization that nonpeptide antigens can stimulate specific CTL responses in several diseases, more and more antigens are likely to be identified as relevant candidates for vaccine development. Finally, automation of the antigen identifica- tion process by algorithms that automate mass spectrometry peptide sequencing ${ }^{14}$ will result in high-throughput antigen identification. For example, a library could be developed consisting of the entire collection of peptides presented by $\mathrm{MHC}$ molecules on different cells under normal or diseased stages. Peptide sequences lead, of course, to gene sequences, and thus, a functional antigenics peptide library would help identify numerous genes, either known or new, whose proteins are targeted for cellsurface display during normal or diseased conditions, enabling new therapeutic targets to be investigated.

\section{Conclusions}

From the corporate side, there is no doubt that functional antigenics delivers drug leads that address a very good market. Therapies based on the immune system have represented good business opportunities, and there is little reason to believe this will not be the case in the future. At present, the world market for immunotherapies, consisting of vaccines, cytokines, immunomodulators, and specific monoclonal antibodies, was estimated to be $\$ 8$ billion in 1995, growing by $15-20 \%$ per annum ${ }^{15}$. By the year 2000 , new products could drive market revenues as high as $\$ 13$ billion.

The technologies described as functional antigenics share the advantage of many successful biotechnology products in augmenting a natural process as part of the healing process. As the body's own CTLs are part of the assay by which specific antigens are chosen in these methods, these approaches have the advantage of demonstrating clinical relevance from the outset. While this suggests that these antigens, once identified, will be ready to enter clinical trials immediately, the reality is likely to depend also on developing safe and effective delivery methods for this powerful platform technology.

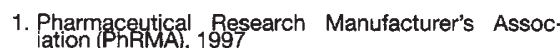
. Persidis, A. 1997. Nature Biotechnol. 15:1409-1411

3. Such antigens are mostly peptides, but they can also be glycopeptides, lipopeptides, or other types of nonpeptide molecule.

4. Vose, B.M. and Bonnard G.D. 1982. Nature 296:359.

5. Murphy, G. et al. 1996. Prostate 29:371-380.

6. Kawakami, Y. et al. 1995. J. Immunol. 154:3961-3968.

7. Mayordomo, J.I. et al. 1995. Nat. Med. 1:1297-1302.

8. Vajda, S. and DeLisi, C. 1990. Biopolymers 29:1755.

9. Skipper, J.C.A. et al. 1996. J. Exp. Med. 183:527-534.

10. Meadows, L. et al. 1997. Immunity 6:273-281.

11. van der Bruggen, P. et al. 1991. Science 254:1643-1647.

12. Henderson, R.A. et al. 1993. Proc. Nati. Acad. Sci. USA 90:10275-10279.

13. Melief, C. et al. 1988. Ann. NY Acad. Sci. 532:280-291.

14. McCormack, A.L. et al. 1997. Anal. Chem. 69:767-776.

15. Evers, P. 1996. Immunotherapy: Current status and markets. Financial Times Management Reports.

\title{
KEEP PACE...
}

\section{With The Changing Biotechnology Marketplace.}

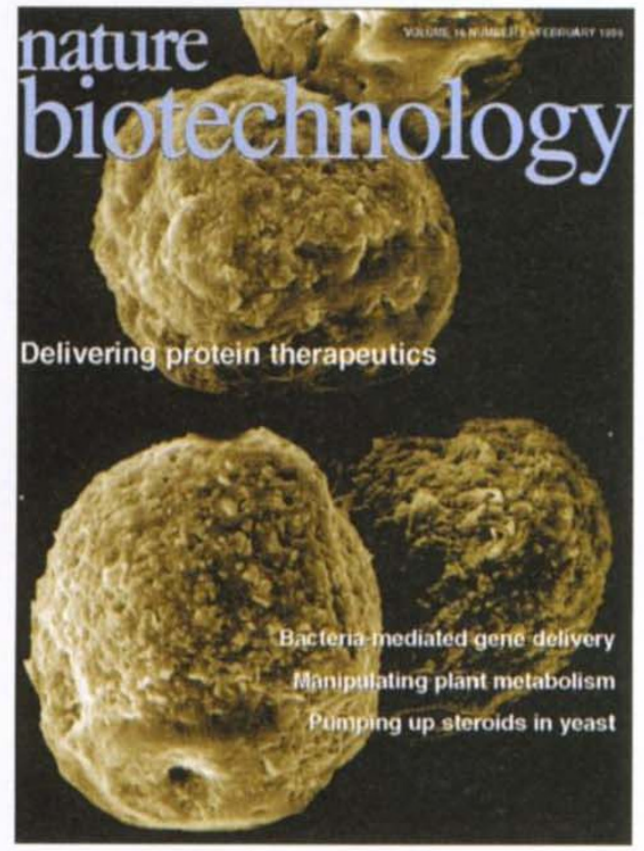

\author{
Whatever aspect of Biotechnology \\ concerns you, you'll find it covered best \\ in Nature Biotechnology.
}

\author{
Subscribe to Nature Biotechnology, \\ the leading journal in its field.
}

START YOUR SUBSCRIPTION TODAY!

\section{See the insert card in this issue for details!}

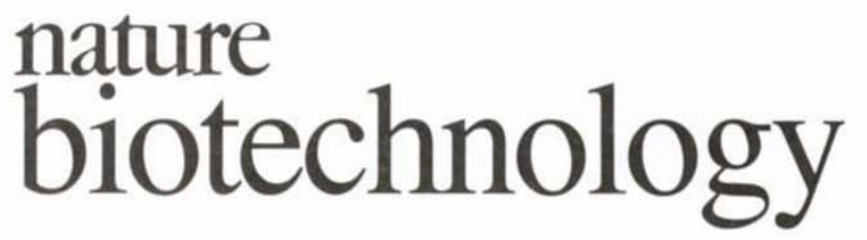

